\title{
correspondence
}

\section{Industry and Academics}

SiR,--I would like to comment on your leading article "Why industry and academics go their separate ways" (September 25).

Whereas in the large industrial countries, in spite of the problems cited in the article, there is probably always enough dialogue between research and industry to produce good results, in small countries like Norway scientific effort has to be very carefully husbanded. They cannot afford the luxury of laissez faire in research and development, and somehow they have to overcome the pre-development, evaluation and identification gaps, even if they don't satisfactorily solve them.

I have been living for much of the past 12 years in Norway, working in, or in the closest vicinity of, an interesting semi-academic institution which represents one solution to the problem presented in your article. This institution has been in existence for 25 years now, is still flourishing, and is therefore perhaps worthy of mention. It consists of a contract organisation by the name of SINTEF, situated on the campus of the Norwegian Technical University. It has a staff of some 650 people, of whom 350 are university graduates or the equivalent. In that it works hand-in-glove with the university, it is instrumental in keeping the latter in close touch with industrial trends, and in that most of its income is derived from industrial projects, it is unable itself to stray too far from industrial needs.

SINTEF is a non-profit-distributing organisation, with a board consisting of academics and industrialists. Money from the National Research Council is obtained largely according to the project in hand, and often on a $50-50$ basis with an industrial partner. Good ideas generated internally are backed internally until ripe enough for presentation to industry, at which point they are then, in the ideal situation, developed into a marketable product at industry's expense. Good ideas, or requirements, from industry are brought to SINTEF for fundamental development because the latter has by now built up a solid reputation for quality, timeliness and (believe it or not) budget consciousness. A fairly thorough presentation of SINTEF will be published shortly in the European Journal of Engineering Education.
I often ask myself why this tripartite symbiosis actually works, and I think there are at least three good reasons. First, the university is not isolated from industry as so many are in larger countries. Second, a substantial number of research-oriented people get a great kick out of seeing their ideas actually transformed into a product, ensuring an adequate supply of employees. And third, Norway actually benefits from being small in that industry knows what SINTEF is, and can very easily get in touch with the appropriate people.

If there is a fourth important reason, I would say it is that a country like Norway simply doesn't have the national resources to turn research and development into a holy cow. Apply your research or starve. Perhaps one of the salutary results of Britain's tragic situation today will be precisely this

Trondheim, Norway

Norman SANDERS

\section{EEC directives}

SIR,-Eric Ashby (October 16) says that "all pollution except that from atomic weapons is a by-product of processes which benefit society".

Lord Ashby must have walked sometimes through a busy street and been assailed by a barrage of traffic noise from cars and heavy lorries (all necessary?) and breathed in their exhaust fumes. Perhaps he might have gone into a restaurant or cinema and filled his lungs with tobacco smoke. There is a vast amount of packaging of food in plastic and the like, much of it for the sake of advertising. Many people are engaged for eight hours or more per day with sheer monotonous routine work making products which have more to do with status than with benefit. Can Lord Ashby honestly believe, therefore, that much of what is manufactured in our society is beneficial?

Why is it a phony argument for the EEC to assert that a Scottish mill discharging into the Atlantic will unfairly compete with a mill on the Rhine which has to comply with stringent standards? Surely, if a uniform standard were not applied to all factories, then only those factories which could pollute the environment unabated would remain in existence while others under stringent control would go out of business. After all, Lord Ashby did mention that he was in argeement with the EEC's long term objective concerning the purity of the sea.

Lord Ashby did not like the idea of regular monitoring of the beaches for pollutants, and his main objection was that it would cost $£ 100$ million a year (a guess by the Department of Environment). He supports his objection by mentioning a report made by the Medical Research Council in 1959 which stated that, in spite of the smelliness and ugliness of many beaches, they were not a hazard to health. Even if the conclusion of the report were absolutely correct, has a report published 16 years ago any relevance to what is happening today and could happen in the future as regards the pollution of the sea?

The gist of Eric Ashby's article seems to me to be: 'We're not going to let a lot of foreigners tell us what to do'. The 'foreigners' seem, however, to be much more willing to tackle pollution than do the powers that be in Britain. Paul C. French

Blommenholm, Norway

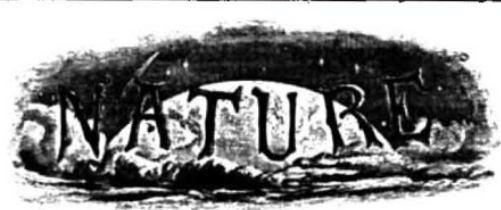

\section{A hundred years ago}

AT last Friday's lecture by Dr. Carpenter, in connection with the St Thomas Charterhouse School Teachers' Science Association, Dr. Lyon Playfair presided. In proposing a vote of thanks to Dr. Carpenter, Dr. Playfair referred to the subject of compulsory education which is gradually becoming universal in this country, but which, he said, would be pure tyrrany unless the education in our schools was increased and its quality raised. Quantity is all very good, but unless there is quality along with it, there is not much gained. "If it was to be said that children of thirteen or fourteen years of age were merely to receive the same education would be but tyranny. Therefore compulsory education involved higher education." Dr. Playfair expressed his gratification that the teachers composing the Association had banded themselves together in order to qualify themselves by attending such lectures as those of the Gilchrist fund and by other means, to undertake this higher education, which, we believe with Dr. Playfair, will be forced upon us even in elementary schools by the spread of compulsory education.

from Nature, 13, 35, Nov. 11, 1875. 